\title{
USE OF SELF-Organizing NeURAL NETWORK IN MOdern MaNUfaCtURING SYSTEMS
}

\author{
VAUPOTIC, B.; BREZOCNIK, M. \& BALIC, J.
}

Abstract: The paper presents the use of nonparametric non-linear model in modern manufacturing processes. Our problem was solved by the use of self-organizing neural network by the method of elastic tape representing the discrete optimization problem. An up-to-data modular programme with graphic environment was used to build the neural network. The user interface ensures entering and changing of different parameters during learning and testing of the artificial neural network. Desired results were reached only by correct selection of the neural network parameters. The results show that the proposed model successfully solves a certain optimization problem and it can be incorporated into the intelligent manufacturing system so that it functions autonomously in the environment with slight interference of the human into the system.

Key words: Self-organizing neural network, Travelling salesman problem, Optimization, Tool motion
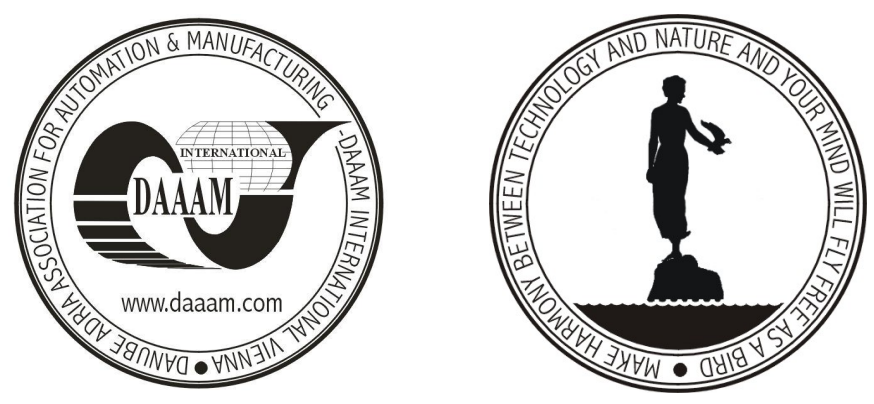

Authors' data: B.Sc. Vaupotic, B[ostjan]; D. Sc. Mech.-Eng. Brezocnik, M[iran]; D.Sc. Prof. Balic, J[oze], University of Maribor, Faculty of mechanical engineering, Intelligent Manufacturing Systems Laboratory, Smetanova 17, SI - 2000 Maribor, Slovenia, bostjan.vaupotic@uni-mb.si,mbrezocnik@uni-mb.si,joze.balic@uni-mb.si

This Publication has to be referred as: Vaupotic, B.; Brezocnik, M. \& Balic, J. (2007). Use of Self-Organizing Neural Network in Modern Manufacturing Systems, Chapter 12 in DAAAM International Scientific Book 2007, B. Katalinic (Ed.), Published by DAAAM International, ISBN 3-901509-60-7, ISSN 1726-9687, Vienna, Austria

DOI: $10.2507 /$ daaam.scibook.2007.12 